\title{
RANGE EXPANSION OF PACHYCHILON MACEDONICUM (ACTINOPTERYGII: CYPRINIFORMES: CYPRINIDAE) IN NORTHERN GREECE
}

\author{
Dimitra C. BOBORI ${ }^{1,2^{*}}$, Georgios ROMANIDIS-KYRIAKIDIS ${ }^{1}$, Chrysoula NTISLIDOU ${ }^{1}$, \\ Olga PETRIKI ${ }^{1}$, and Athina PATSIA ${ }^{1,2}$ \\ ${ }^{1}$ Aristotle University of Thessaloniki, School of Biology, Department of Zoology, \\ Laboratory of Ichthyology, Thessaloniki, Greece \\ ${ }^{2}$ Management Body of Lakes Koronia-Volvi, Thessaloniki, Greece
}

\begin{abstract}
Bobori D.C., Romanidis-Kyriakidis G., Ntislidou Ch., Petriki O., Patsia A. 2014. Range expansion of Pachychilon macedonicum (Actinopterygii: Cypriniformes: Cyprinidae) in northern Greece. Acta Ichthyol. Piscat. 44 (4): 319-321.

Abstract. The cyprinid freshwater fish, Pachychilon macedonicum (Steindachner, 1892), is an endemic species in the Balkan Peninsula and has a restricted distribution in Greece. Here, we report new records of the species out of its known natural range, namely at the Mpogdanas Stream (drainage area of lakes Koronia-Volvi, northern Greece), which now constitute a new eastern limit for the distribution of the species in southern Balkans. It appears that the new record is related to a human-mediated translocation.
\end{abstract}

Keywords: endemics, south Balkan Peninsula, freshwater fish distribution, eastern limit

The cyprinid freshwater fish, Pachychilon macedonicum (Steindachner, 1892), endemic to the south Balkan Peninsula, is recognized as a rare species, locally 'vulnerable' (Oikonomidis 1991). It represents a Danubian cyprinid species that dispersed during the upper Pliocene and Pleistocene following three main corridors, including the direct route through the Morava-Axios valley (Economidis and Banarescu 1991). The taxonomic position of the species is rather complex (for a synopsis see Ráb et al. 2000). However, osteological (Šorić 1992) and genetic (Ráb et al. 2000) studies confirm that $P$. macedonicum is clearly distinct from Rutilus, where Karaman (1972) had initially placed Pachychilon as a subgenus.

Pachychilon macedonicum has a restricted distribution (for a review see Kottelat and Freyhof 2007). It occurs to the Axios River basin in Greece and FYROM (see synopsis of Ráb et al. 2000, Georgiev 2004, Economou et al. 2007), including the transboundary Lake Doirani (Oikonomidis 1991, Economou et al. 2007, Bobori and Salvarina 2010, Vavalidis et al. 2010, Kostov et al. 2011). In Greece it has also been reported in rivers Loudias and Mavroneri (Economidis et al. 1981, Froese and Pauly 2014), the lower parts of the Aliakmon and Pinios Rivers, as well as to the Lake Karla basin (Oikonomidis 1991, Economou et al. 2007, Economidis and Bobori unpublished ${ }^{* *}$, Kottelat and Freyhof 2007).
It is a small bodied species, with maximum total length of $14.5 \mathrm{~cm}$ (Vavalidis et al. 2010), easily recognized by having a broad black stripe from the tip of the snout to the middle of the caudal fin base and a vertically elongated black blotch at the caudal base (Kottelat and Freyhof 2007). The species occurs in marshlands, lakes, and watercourses on the low plains, with little current (Froese and Pauly 2014). The biology and ecology of the species is very little known. Typically, it lives in small groups, moving during the winter in sheltered places. It preys mainly on chironomids and its trophic level has been estimated as $3.2 \pm 0.4$ (Vavalidis et al. 2010). It is threatened mainly by water extraction and pollution, as well as habitat alteration (Oikonomidis 1991).

In the present work we report the expansion and settlement of the endemic species Pachychilon macedonicum in the Mpogdanas Stream, which flows into Lake Koronia (Fig. 1) (northern Greece, south Balkans). The area constitutes part of the national park of lakes Koronia-Volvi and it is protected under the Ramsar Convention as a wetland site of international importance, the Habitats' Directive (92/43/EU), and it is an Important Area for birds (79/409/EU).

A total of 25 specimens of Pachychilon macedonicum (total length TL: $3.4-9.2 \mathrm{~cm}$, total weight TW: $0.5-14.4 \mathrm{~g}$ ) were collected during the fish monitoring surveys carried

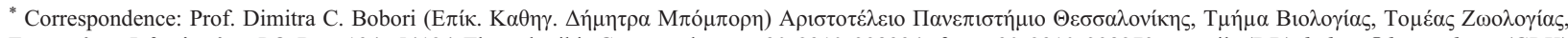

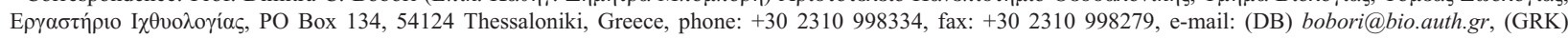
groman_1986@hotmail.com, (CN)chntisli@windowslive.com, (OP) opetriki@bio.auth.gr, (AP) a_patsia@hotmail.com

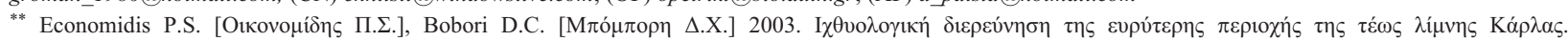
[Ichthyological study in the area of the former Lake Karla.] Technical report. [In Greek.]
} 
out in two periods of low flow (LF; October 2012) and high flow (HF; April 2013). Specimens were captured by electrofishing (Anonymous 2003) at 4 out of the 9 sampling stations, located at the upper part of the Mpogdanas Stream (Fig. 1, Table 1), since it usually dries out at its lower parts during most of the year, under the permission of the Management Body of Lakes Koronia-Volvi. The majority of specimens (10) were captured at station MP4 during the HF period. This station has permanent flow and receives the treated wastewaters of a landfill located upstream. Moreover, at this station the highest diversity was recorded since seven more species were also captured: Barbus strumicae Karaman, 1955; Squalius orpheus Kottelat et Economidis, 2006; Cobitis strumicae
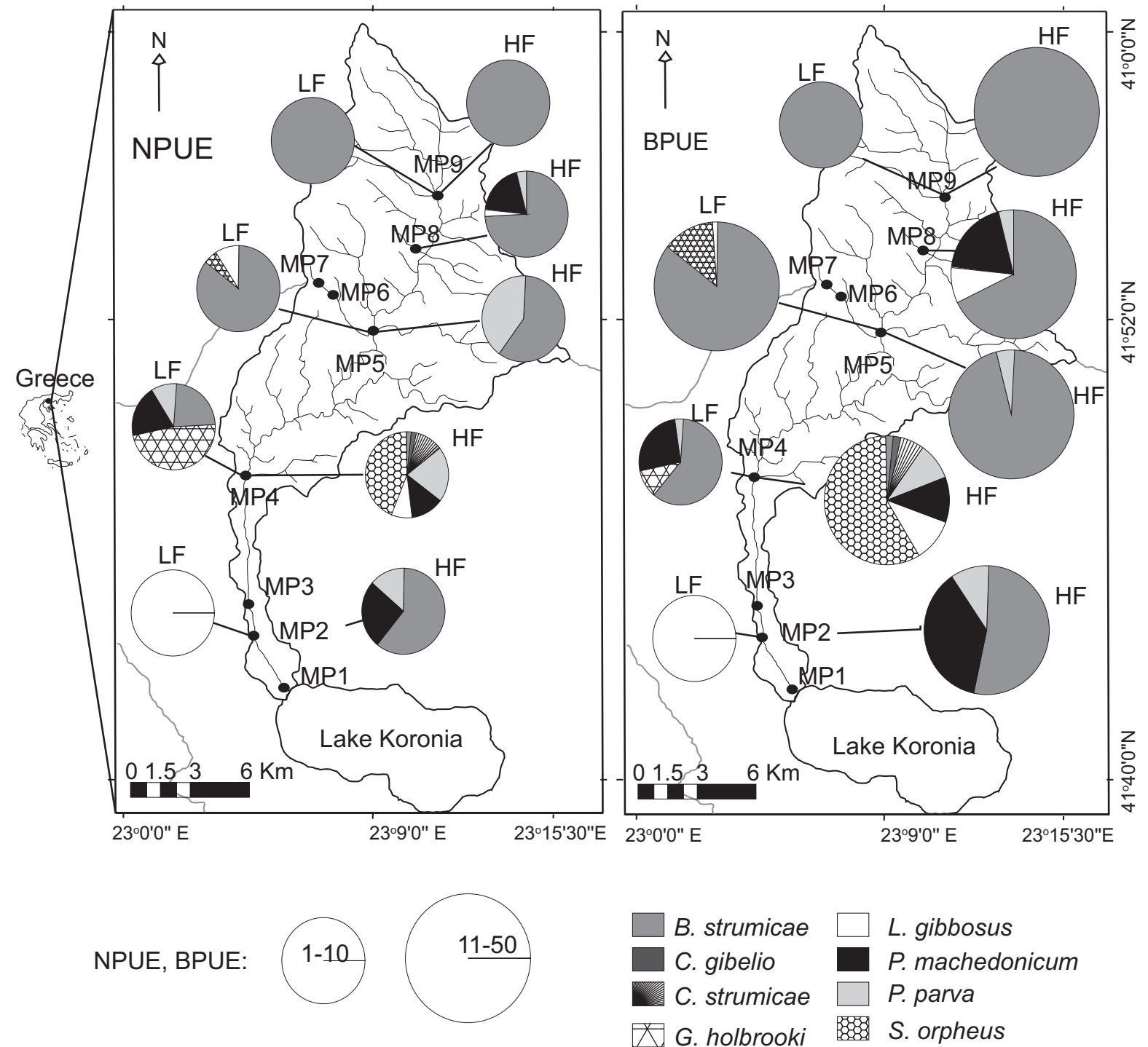

Fig 1. The drainage basin of Mpogdanas stream with the sampling stations (MP1 - MP9); The abundances of all fish species caught are provided in terms of NPUE (number of Pachychilon macedonicum individuals per $100 \mathrm{~m}^{2}$ of sampling area) and BPUE (g per $100 \mathrm{~m}^{2}$ of sampling area) for both sampling periods of low (LF) and high (HF) flow

Table 1

Sampling location and descriptive characteristics of Pachychilon macedonicum specimens caught in the Mpogdanas Stream (northern Greece), during the low flow (October 2012) and high flow (April 2013) periods

\begin{tabular}{lcccccccc}
\hline Station & Flow & Altitude $[\mathrm{m}]$ & Coordinates & Total length $[\mathrm{cm}]$ & Total weight $[\mathrm{g}]$ & $n$ & NPUE & BPUE $[\mathrm{g}]$ \\
\hline MP4 & Low & 143 & $40^{\circ} 48^{\prime} 2^{\prime \prime} \mathrm{N}, 23^{\circ} 3^{\prime} 23^{\prime \prime} \mathrm{E}$ & $4.94 \pm 0.78$ & $2.02 \pm 1.17$ & 5 & 0.91 & 2.30 \\
MP2 & High & 97 & $40^{\circ} 43^{\prime} 45^{\prime \prime} \mathrm{N}, 23^{\circ} 3^{\prime} 47^{\prime \prime} \mathrm{E}$ & $8.10 \pm 0.40$ & $8.98 \pm 2.09$ & 4 & 0.44 & 3.98 \\
MP4 & High & 143 & $40^{\circ} 48^{\prime} 2^{\prime \prime} \mathrm{N}, 23^{\circ} 3^{\prime} 23^{\prime \prime} \mathrm{E}$ & $6.10 \pm 0.50$ & $4.29 \pm 1.11$ & 10 & 1.08 & 4.64 \\
MP8 & High & 450 & $40^{\circ} 53^{\prime} 48^{\prime \prime} \mathrm{N}, 23^{\circ} 53^{\prime} 48^{\prime \prime} \mathrm{E}$ & $5.50 \pm 0.70$ & $3.07 \pm 1.10$ & 6 & 1.55 & 4.76 \\
\hline
\end{tabular}

Length and weight values are mean \pm standard error; $n=$ number of fish individuals, NPUE $=$ number of individuals caught per $100 \mathrm{~m}^{2}$ of sampling area, BPUE $=$ weight of individuals caught per $100 \mathrm{~m}^{2}$ of sampling area. 
Karaman, 1955; Lepomis gibbosus (Linnaeus, 1758); Pseudorasbora parva (Temminck et Schlegel, 1846); Carassius gibelio (Bloch, 1782); and Gambusia holbrooki Girard, 1859 (Fig. 1). Furthermore, P. macedonicum was found at station MP2, during the HF period, which also receives the same treated wastewaters. However, the species appeared more abundant in terms of number (NPUE: 1.55 individuals per $100 \mathrm{~m}^{2}$ of sampling area) and weight (WPUE: $4.76 \mathrm{~g}$ per $100 \mathrm{~m}^{2}$ of sampling area) at station MP8 (Fig. 1, Table 1), which considered unpolluted. It seems that $P$. macedonicum can adapt to several environments and tolerate, such as many cyprinids (Karr 1981), unfavourable environments.

The presence of Pachychilon macedonicum in the area cannot easily be explained, since the Mpogdanas Stream is not linked to the River Axios basin, which is the closest aquatic ecosystem where the species had hitherto been reported. It is also worth mentioning that the species was not found during an intensive previous study carried out in the area (Kokkinakis et al. unpublished ${ }^{*}$ ). Thus, we can hypothesize that the species has accidentally been introduced to the system, possibly during a transportation of other species of commercial importance (e.g., perch). However, the existence of the species in different locations provides evidence for its successful adaptation.

In conclusion, our findings confirm the existence of Pachychilon macedonicum eastward of its native distribution area, with the Mpogdanas Stream been now the eastern limit of its distribution. Furthermore, due to the inflow of the Mpogdanas Stream into Lake Koronia, a wider distribution of the species can be expected, when the hydrological conditions become favourable. The surface running water network in the wider area is quite dense (Fig. 1) and the lake can potentially act as an intermediate route (Muhlfeld et al. 2012) for nourishing streams with P. macedonicum. Nonetheless, the available data are not sufficient to support these hypotheses and more studies need to be carried out in the area.

\section{REFERENCES}

Anonymous 2003. Water quality-Sampling of fish with electricity. European Standard Ref.No. EN 14011: 2003 E. European Committee For Standardization, Brussels, Belgium.

Bobori D.C., Salvarina I. 2010. Seasonal variation of fish abundance and biomass in gillnet catches of an East Mediterranean lake: Lake Doirani. Journal of Environmental Biology 31 (6): 995-1000.

Economidis P.S., Banarescu P.M. 1991. The distribution and origins of freshwater fishes in the Balkan Peninsula, especially in Greece. Internationale Revue der gesamten Hydrobiologie und Hydrografie 76 (2): 257-283. DOI: 10.1002/iroh.19910760209

Economidis P.S., Kattoulas M.E., Stephanidis A. 1981. Fish fauna of the Aliakmon River and the adjacent waters (Macedonia, Greece). Cybium 5 (1): 89-95.
Economou A.N., Giakoumi, S., Vardakas I., Barbieri, R., Stoumboudi M., Zogaris S. 2007. The freshwater ichthyofauna of Greece - an update based on a hydrographic basin survey. Mediterranean Marine Science 8 (1): 91-166. DOI: 10.12681/mms. 164

Froese R., Pauly D. (eds.) 2014. FishBase. [version 04/2014] http://www.fishbase.org

Georgiev S.B. 2004. Sadašnje poznavanje endemizma ihtiofaune Republike Makedonije. [Present knowledge on the endemicity of the ichthyofauna of the Republic of Macedonia.] Ribarstvo 62 (2): 43-58. [In Croatian.]

Karaman S. 1972. Süsswasserfische der Türkei. 9. Revison einiger kleinwüchsiger Cypriniden gattungen Phoxinellus, Leucaspius, Acanthobrama usw. Aus Südeuropa, Kleinasien, Vorder-Asien und Nordafrika. Mitteilungen aus dem Hamburgischen Zoologischen Museum und Institut 69: 115-155.

Karr J.R. 1981. Assessment of biotic integrity using fish communities. Fisheries 6 (6): 21-27. DOI: 10.1577/15488446(1981)006<0021:AOBIUF>2.0.CO;2

Kostov V., Ristovska M., Slavevska-Stamenković V., Miljanović B., Paunović M. 2011. Setting up a system for ecological status assessment based on fish fauna - the Pčinja River-case study. Macedonian Journal of Animal Science 1 (2): 369-376. DOI: 597.2/.5/497.721:282

Kottelat M., Freyhof J. 2007. Handbook of European freshwater fishes. Kottelat and Freyhof, Cornol, Switzerland, Berlin, Germany.

Muhlfeld C.C., Giersch J.J., Marotz B. 2012. Seasonal movements of non-native lake trout in a connected lake and river system. Fisheries Management and Ecology 19 (3): 224-232. DOI: 10.1111/j.1365-2400.2011.00821.x

Oikonomidis P.S. [Economidis P.S.] 1991. Katálogos tōn psariốn tou glykoú neroú tīs Elládas. Sīmerin̄i katástasī kindýnōn kai prostasía. [Check list of freshwater fishes of Greece (Recent status of threats and protection).] Ellīnikī Etaireía gia tīn Prostasía tīs Phýsīs [Hellenic Society for the Protection of Nature], Athens, Greece. [In Greek.]

Ráb P., Rábová M., Economidis P.S., Triantaphyllidis C. 2000. Banded karyotype of the Greek endemic cyprinid fish, Pachychilon macedonicum. Ichthyological Research 47 (1): 107-110. DOI: 10.1007/BF02674321

Šrić V. 1992. Osteology and taxonomic status of the genus Pachychilon Steind., 1882 (Pisces, Cyprinidae). Bios (Macedonia, Greece) Scientific Annals of the School of Biology 1: 49-67.

Vavalidis Th., Bobori D.C., Michaloudi E. 2010. Diet composition of Perca fluviatilis Linnaeus, 1758 and Pachychilon macedonicum (Steindachner, 1892) in Lake Doirani. Pp. 115-118. In: Proceedings of the 14th Panhellenic Conference of Ichthyologists, 6-9 May 2010, Piraeus, Greece. [In Greek with English summary.]

Received: 5 January 2014

Accepted: 19 July 2014

Published electronically: 31 December 2014

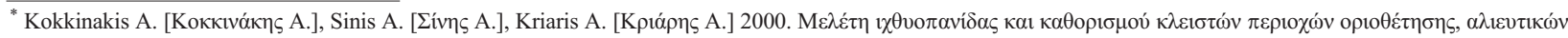

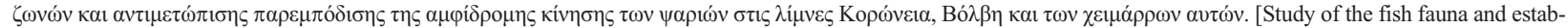
lishment of closed border fishing areas with emphasis on diadromous fish movements in lakes Koronia and Volvi and their torrents.] Technical report. [In Greek.]
} 